\title{
Characteristics and outcomes of in vitro fertilization in different phenotypes of polycystic ovary syndrome
}

\author{
Farklt polikistik over sendromunun fenotiplerinin in vitro \\ fertilizasyon özellikleri ve sonuçlarının karşılaştırılması
}

\author{
Selçuk Selçuk1, Enis Özkayal, Ahmet Eser1, Melda Kuyucul, Hüseyin Tayfun Kutlu1, Belgin Devranoğlu1, \\ Kenan Sofuoğlu2, Vedat Erkan Dayıcıoğlu1 \\ 1Zeynep Kamil Women and Children's Diseases Education and Research Hospital, Clinic of Obstetrics and Gynecology, İstanbul, Turkey \\ ${ }^{2}$ Medistate Hospital, Clinic of Obstetrics and Gynecology, İstanbul, Turkey
}

\begin{abstract}
Objective: The aim of this study was to investigate whether polycystic ovary syndrome (PCOS) phenotype without polycystic ovaries (PCO) differs in terms of in vitro fertilization (IVF) outcomes compared with classic phenotypes.

Materials and Methods: This retrospective controlled study included 262 patients who underwent IVF treatment with an indication of unexplained or tubal factor infertility (control group), ovulatory patients with PCO morphology (group 1), PCOS phenotype with oligoanovulation and hyperandrogenemia (group 2), PCOS phenotype with PCO morphology and oligoanovulation (group 3). Outcomes and baseline characteristics of IVF-embryo transfer treatments were compared among all groups.

Results: PCOS phenotype without PCO morphology had similar IVF stimulation characteristics compared with classic phenotypes; however, a higher total gonadotropin dose was needed to achieve similar results compared with patients with PCO morphology with or without PCOS. Basal follicle-stimulating hormone level (beta coefficient $=0.207, \mathrm{p}=0.003$ ), group (beta coefficient $=-0.305, \mathrm{p}<0.001$ ) and age (beta coefficient $=0.311$, $\mathrm{p}<0.001$ ) were significantly associated with the total gonadotropin dose. The number of good quality embryo on transfer day was significantly lower in patients with isolated PCO morphology and PCO morphology with oligoanovulation than in those with PCOS phenotype without PCO morphology.

Conclusion: PCO morphology provides easier stimulation, whereas hyperandrogenemia provides better results as good quality embryos. However, the end point is similar in terms of biochemical, clinical, and ongoing pregnancy rates.
\end{abstract}

Keywords: Polycystic ovary syndrome, IVF, phenotypes

$\ddot{0} z$

Amaç: Bu çalışmada polikistik over sendromunun (PKOS) farklı fenotiplerinin in vitro fertilizasyon (IVF) sonuçlarının karşılaştırılması amaçlandı. Gereç ve Yöntemler: Bu retrospektif çalışmaya IVF tedavisi uygulanmış açıklanamayan veya tubal faktör infertilitesi olan hastalar (kontrol grup), polikistik over (PKO) morfolojisi olan ovulatuar hastalar (grup 1), oligo-anovulasyonu ve hiperandrojenemisi olan PKOS'lu hastalar (grup 2), PKO morfolojisi ve oligo-anovulasyonu olan hastalar (grup 3) olmak üzere toplam 262 hasta dahil edildi. Gruplar uygulanan IVF-embriyo transferi tedavisinin özellikleri ve sonuçları açısından karşılaştırıldı.

Bulgular: PKO morfolojisi olmayan PKOS’lu olgular; klasik PKOS fenotipi olan olgularla karşılaştırldığında benzer over stimulasyon özellikleri göstermektedir ancak PKO morfolojisi olan olgulara göre daha yüksek gonadotropin dozu gerekmektedir. Bazal folikül uyarıcı hormon düzeyi (beta kat sayısı=0,207, p=0,003), grup (beta kat sayısl=-0,305, $<<0,001$ ) ve yaş (beta kat sayısl=0,311, p<0,001) toplam gonadotropin dozuyla istatistiksel olarak anlamlı derecede ilişkili bulundu. İzole PKO morfolojisi olan olguların ve oligo-anovulasyonu olup PKO morfolojisi olan olguların transfer günü iyi kalite embriyo sayısı, PKO morfolojisi olmayan PKOS'lu olgulara göre istatistiksel olarak anlamlı düzeyde daha düşük tespit edildi.

Sonuç: PKO morfolojisinin varlığının over stimulasyonunu kolaylaştırdığı, hiperandrojeneminin de embriyo kalitesi üzerine olumlu etkilerinin olduğu saptandı. Ancak gruplar arasında; biyokimyasal gebelik, klinik gebelik ve devam eden gebelik oranları açısından fark tespit edilmedi.

Anahtar Kelimeler: Polikistik over sendromu, IVF, fenotip 


\section{Introduction}

Polycystic ovary syndrome (PCOS) is a complex disorder and may present in different phenotypes. Previous data included only the classic phenotype characterized by chronic anovulation and hyperandrogenism(1-3). However, accumulated data led to the Rotterdam criteria, which allows for different PCOS phenotypes(4). According to the defined criteria, four different phenotypes can be introduced: I. Hyperandrogenism, chronic anovulation, and polycystic ovaries (PCO); II. Hyperandrogenism and chronic anovulation but normal ovaries; III. Hyperandrogenism and polycystic ovaries but ovulatory cycles; and IV. Chronic anovulation and polycystic ovaries but no clinical or biochemical hyperandrogenism. A meta-analysis concluded that unknown intra-or extraovarian abnormalities may interfere with granulosa cell-oocyte interaction, oocyte maturation, and potential embryonic development and result in unsuccessful artificial reproduction techniques in PCOS(5). However, it is not known whether different phenotypes of PCOS have similar results. It is well known that PCOS is associated with elevated adrenal androgens such as dehydroepiandrosterone sulphate (DHEAS) in 20-50\% of cases and meta-analyses about the effect of DHEAS supplementation in assisted reproduction revealed improvement of oocyte production and pregnancy rates (6-9). However, according to the aforementioned data, we know that all PCOS phenotypes do not have hyperandrogenemia or even PCO morphology, so is it possible to generalize all in vitro fertilization (IVF) outcomes in PCOS by assessing a mixture of women with different PCOS phenotypes?

In this study, we aimed to assess IVF characteristics among different PCOS phenotypes to show whether PCO morphology or hyperandrogenemia would interfere with the results.

\section{Materials and Methods}

\section{Study population}

Between 2009 and 2014, among the women referred to the infertility unit of the Department of Obstetrics and Gynecology, Zeynep Kamil Women and Children's Health Training and Research Hospital, 262 patients who underwent IVF treatment with an indication of unexplained or tubal factor infertility (control group, $n=84$ ), ovulatory patients with isolated PCO morphology (group $1, \mathrm{n}=85$ ), PCOS phenotype with oligoanovulation and hyperandrogenemia (group 2, n=38), PCOS phenotype with PCO morphology and oligoanovulation (group $3, \mathrm{n}=55$ ) were enrolled in the study (Table 1). Sample size was calculated according to the study by Kim et al.(10) with 95\% confidence interval (CI) and $80 \%$ power. The exclusion criteria were age $\geq 40$ years; body mass index (BMI) $>35 \mathrm{~kg} / \mathrm{m}^{2}$; basal folliclestimulating hormone (FSH) level >12 mIU/mL; presence of endometriosis; three or more previous unsuccessful IVF treatment; and systemic illness or endocrine disorders such as hyperprolactinemia, hypothyroidism, Cushing's syndrome and non-classic congenital adrenal hyperplasia. The groups were compared in terms of basal clinical characteristics and IVF outcomes. PCO morphology was determined based on the data from transvaginal ultrasound showing the presence of 12 or more peripherally-oriented cystic structures in one ultrasonographic plane, each of which measured 2 to 10 $\mathrm{mm}$ in diameter(11). Oligo-anovulation was described as progesterone $<3 \mathrm{ng} / \mathrm{mL}$ ( $<9.54 \mathrm{nmol} / \mathrm{L}$ ) on days $18-21$ and/ or a menstrual cycle of longer than 35 days. Patients with an elevated serum testosterone $>60 \mathrm{ng} / \mathrm{dL}(>2.08 \mathrm{nmol} / \mathrm{L})$ and/or serum $\Delta 4 \mathrm{~A}$ levels $>3.8 \mathrm{ng} / \mathrm{mL}$ were considered to have biochemical hyperandrogenemia and subjects with a Ferriman Gallwey score $>8$ were accepted as having clinical hyperandrogenemia(12). The study protocol was approved by the Local Ethics Committee of Zeynep Kamil Research and Teaching Hospital.

\section{Treatment protocol}

On cycle day 3, ovarian stimulation was started by daily injection of recombinant FSH (r-FSH) (Gonal-F, Merck Serono, İstanbul, Turkey) with a starting dose specific for cases according to their age, BMI, ovarian reserve, and antral follicle count (AFC). According to the antagonist protocol, gonadotropinreleasing hormone $(\mathrm{GnRH})$ antagonist (Cetrotide; $0.25 \mathrm{mg}$; Merck Serono, İstanbul, Turkey) injection was started from the $6^{\text {th }}$ day of stimulation. Monitorization of the cycles was based on the ultrasound examination to record the number and size of the follicles and the double-layer endometrial thickness. For each participant on cycle days 2-3, transvaginal ultrasound was performed to determine AFC and screen for ovarian cysts. A repeat examination was performed on day 6 of stimulation and subsequently every 1-3 days as clinically indicated until the criterion for subcutaneous administration of recombinant chorionic gonadotropin alpha $250 \mathrm{mg}$ (Ovitrelle; Merck-Serono, İstanbul, Turkey) was reached; at least two follicles $\geq 17 \mathrm{~mm}$ in diameter. Ovum retrieval was performed $36 \mathrm{~h}$ later. In all cases, an intracytoplasmic sperm injection procedure was performed on the same day (day 0) and embryo transfer was performed on day 3, 4 or 5 based on the quality of embryos. From the day of ovum retrieval, the luteal phase was supported by progesterone intravaginally (Crinone 8\% gel; Serono, İstanbul, Turkey) twice a day.

\section{Assessment of embryo quality}

Table 1. Clinical characteristics of patients according to rotterdam criteria in each group

\begin{tabular}{|c|c|c|c|}
\hline & $\begin{array}{l}\text { Polycystic } \\
\text { ovary } \\
\text { morphology }\end{array}$ & $\begin{array}{l}\text { Oligo } \\
\text { anovulation }\end{array}$ & $\begin{array}{l}\text { Clinical and/ } \\
\text { or biochemical } \\
\text { hyperandrogenism }\end{array}$ \\
\hline Group 1 & + & - & - \\
\hline Group 2 & - & + & + \\
\hline Group 3 & + & + & - \\
\hline
\end{tabular}


Embryo quality was described according to the blastomeres size and number, the degree of fragmentation, and the presence of multinucleated blastomeres. Embryos with 4 or 5 equal- sized blastomeres and less than 10\% cytoplasmic fragmentation with no multinucleation were accepted as good quality on day 2 . An embryo with 7 or 8 equal-sized blastomeres with less than $10 \%$ cytoplasmic fragmentation and no multinucleation was accepted as good quality on day 3. A good quality embryo on day 4 was determined with following characteristics: embryo cavitation with compacted properties without morphologic anomalies such as vacuolation, excessive fragmentation, large number of excluded cells, and self-cavitation of cells $(13,14)$. On day 5 , blastocyst quality and expansion were described in accordance with the classification of Gardner and Schoolcraft $(15)$ and good quality embryo was accepted as $\geq$ grade $3 \mathrm{AA}$.

\section{In vitro fertilization treatment outcomes}

Chemical pregnancy was defined as positive $\beta$-hCG test following embryo transfer. Clinical pregnancy was defined as presence of gestational sac with fetal cardiac activity under ultrasonography. An ongoing pregnancy was defined as a pregnancy $\geq 12$ weeks of gestation confirmed with ultrasonographic examination. Data of pregnancy outcomes were obtained from the hospital database or the pregnant women via phone. The implantation rate was calculated by dividing the number of gestational sacs with fetal cardiac activity by the number of embryos transferred. The primary end-points of the study were the chemical pregnancy rate, the clinical pregnancy rate, and ongoing pregnancy rate. Secondary outcomes evaluated were the total gonadotropin dose used, estradiol (E2) level on the trigger day, peak estradiol level, number of dominant follicles, number of metaphase II (MII) oocytes, MII oocytes rate, and implantation rate.

\section{Statistical analysis}

Statistical analysis was performed using SPSS version 11.5 software. All data were summarized using descriptive statistics, correlation analyses were used to show associations, multivariate regression was used to show adjusted associations, receiver operating characteric curve analysis was used to calculate predictive value, and the sensitivity and specificity. One-way ANOVA and Pearson's Chi-square tests were performed where appropriate; $\mathrm{p}=0.05$ was accepted as the degree of significance. Data were given as mean \pm standard deviation or percentage.

\section{Results}

The baseline clinical characteristics of all groups are given in Table 2. There were no significant difference in terms of age, BMI, basal FSH, E2 levels, and duration of infertility among all groups. The characteristics of IVF cycles of patients are detailed in Table 2. The total gonadotropin dose was similar between group 2 and the control group, whereas it was significantly lower in groups 1 and 3 than in other groups $\left(p_{1}=0.002\right.$, $\mathrm{p}_{2}<0.001, \mathrm{p}_{3}=0.006$ ). Basal FSH level (beta coefficient $=0.207$, $\mathrm{p}=0.003$ ), group (beta coefficient $=-0.305, \mathrm{p}<0.001$ ) and age (beta coefficient $=0.311, \mathrm{p}<0.001$ ) were significantly associated with the total gonadotropin dose. There was significant correlation between total gonadotropin dose and age $(r=0.303$, $\mathrm{p}<0.001)$, AFC $(\mathrm{r}=-0.553, \mathrm{p}<0.001)$, basal FSH level $(\mathrm{r}=0.243$, $\mathrm{p}<0.001)$, and group $(\mathrm{r}=-0.243, \mathrm{p}<0.001)$. Age $(\mathrm{AUC}=0.595$, $=0.009)$ and basal FSH level $(\mathrm{AUC}=0.646, \mathrm{p}<0.001)$ were found as significant predictors for the high gonadotropin dose $>1800$ IU, detrimented by the median level (Figure 1). The cutoff value for age was 29.5 years with 58\% sensitivity and 54\% specificity. The cut-off value for basal FSH was 6.2 with $65 \%$ sensitivity and $60 \%$ specificity. There were significantly higher numbers of oocytes retrieved in groups 1 and 3 when compared with patients in the control group; it was similar among groups 1,2 and 3. There was no significant difference with respect to the ratio of MII oocytes and implantation rates among all groups. The number of good quality embryos on transfer day was significantly lower in patients in group 1 and 3 than in group 2. pregnancy rates are shown in Table 3. Biochemical, clinical and ongoing pregnancy rates were found similar among all groups.

\section{Discussion}

In the present study, we aimed to assess IVF characteristics among PCOS phenotypes with and without hyperandrogenemia or PCO morphology. Analyses of the data showed that IVF has similar success rates in patients with PCOS independent of presence or absence of hyperandrogenemia or PCO morphology. However, as expected, PCO morphology provided stimulation with lower doses and needed lower amounts of

\section{ROC Curve}

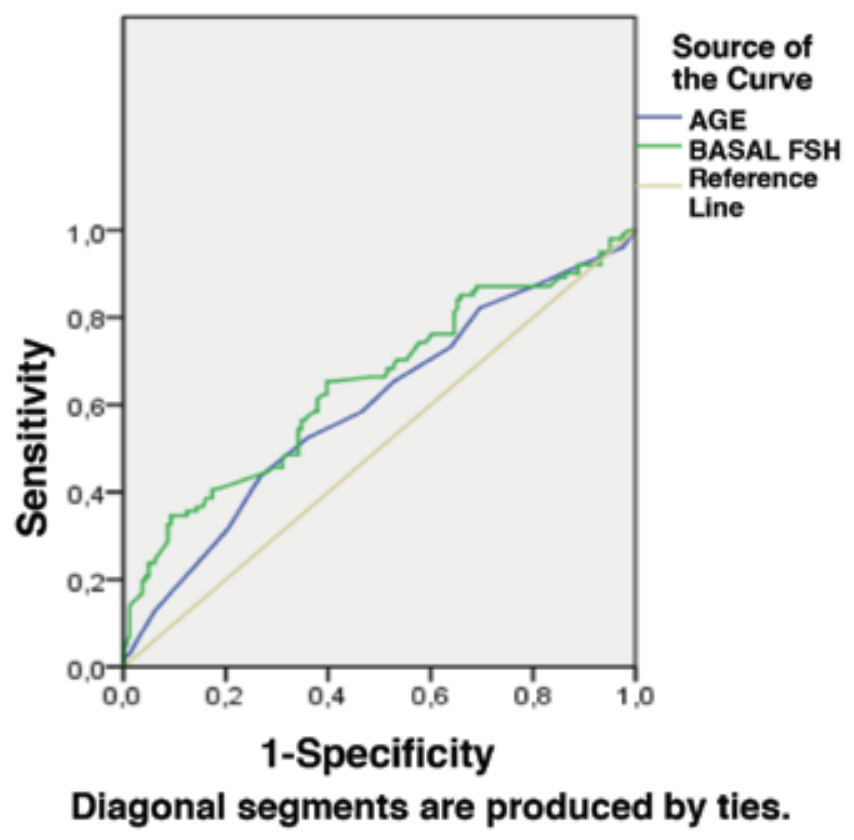

Figure 1. Receiver operating characteric curve of basal follicle stimulating hormone level and age to predict high gonadotropin dose 
total gonadotropin dose. The number of good quality embryos was found to be significantly higher in the PCOS phenotype with oligoanovulation and hyperandrogenemia group. Despite the absence of PCO morphology, the numbers of dominant follicles were found comparable between this group and patients with PCO morphology. Good quality embryos and a comparable number of dominant follicles led us to conclude that hyperandrogenemia may have a favorable effect. However, this group needed a similar total gonadotropin dose when compared with the control group and higher total gonadotropin dose than the groups with PCO morphology. This shows that PCO morphology provides easier stimulation; hyperandrogenemia provides better results in terms of good quality embryos. Jamil et al.(16) compared the clinical and hormonal parameters among four phenotypes of PCOS based on the Rotterdam criteria and with a control group. Women in the oligo-anovulation and PCO group and in the control group had significantly lower levels of luteinizing hormone/FSH ratio, total testosterone, and free androgen index, and higher levels of FSH and sex hormonebinding globulin when compared with women in the oligoanovulation, PCO and hyperandrogenemia groups(16). In the literature, it was stated that androgens were found to have a favorable effect on follicle maturation, especially during the early stages(17). However, other studies showed a negative effect of androgens on folliculogenesis and embryonic development(18).
Androgens have been suggested to have a modulating effect on FSH activity in developing granulosa cells, and studies on PCOS have shown that androgens have a positive and negative effect on folliculogenesis (17). Despite the changing effects of androgens and PCO morphology among groups, the end point is similar in terms of biochemical, clinical, and ongoing pregnancy rates. A recently published study on the effect of PCO morphology on oocyte quality in intracytoplasmic sperm injection cycles compared with a control group showed neither positive nor negative effects and the MII oocyte number was found to be higher in the group with PCO morphology, whereas the ratio of MII oocyte was similar, the number of top quality embryos was comparable between groups but the implantation and clinical pregnancy rates were found significantly higher in the PCO morphology group ${ }^{(19)}$. The authors tried to assess the effect of PCO morphology alone on oocyte quality so their results were not consistent with ours because of the ignored effect of hyperandrogenemia, which was shown to have a favorable effect in our study. In addition, patients with PCOS had similar IVF outcomes compared with other hyperresponders without PCOS in a study by O'Neill et al.(20) Our study also produced similar end results but our data showed some critical cycle characteristics among different PCOS phenotypes. Ryan et al.(21) showed a negative effect of prolonged stimulation in assisted reproductive technology cycles but the authors claimed that this

Table 2. Comparison of baseline clinical characteristics among all groups

\begin{tabular}{|c|c|c|c|c|c|}
\hline & $\begin{array}{l}\text { Group } 1 \\
(n=85)\end{array}$ & $\begin{array}{l}\text { Group } 2 \\
(n=38)\end{array}$ & $\begin{array}{l}\text { Group } 3 \\
(n=55)\end{array}$ & $\begin{array}{l}\text { Control } \\
(\mathrm{n}=84)\end{array}$ & p \\
\hline Age (years) & $29.24 \pm 3.72$ & $30.32 \pm 4.07$ & $29.01 \pm 3.84$ & $30.38 \pm 4.03$ & NS \\
\hline BMI $\left(\mathrm{kg} / \mathrm{m}^{2}\right)$ & $25.29 \pm 4.31$ & $24.53 \pm 2.96$ & $24.28 \pm 4.21$ & $25.42 \pm 2.97$ & NS \\
\hline Basal FSH (mIU/mL) & $6.31 \pm 1.65$ & $6.31 \pm 1.75$ & $6.26 \pm 1.43$ & $6.52 \pm 1.83$ & NS \\
\hline Duration of infertility (years) & $5.90 \pm 3.68$ & $6.84 \pm 4.03$ & $6.09 \pm 4.06$ & $6.79 \pm 3.41$ & NS \\
\hline Duration of stimulation (days) & $8.54 \pm 1.19$ & $8.64 \pm 1.32$ & $8.75 \pm 1.73$ & $8.76 \pm 1.64$ & NS \\
\hline Total gonadotropin dose (IU) & $1608.4 \pm 414.1$ & $2135.5 \pm 956.9$ & $1607.8 \pm 513.9$ & $2307.4 \pm 1008.3$ & $<0.001$ \\
\hline E2 on hcg day (pg/mL) & $2303.1 \pm 1098.5$ & $2061.6 \pm 822.3$ & $2116.9 \pm 1198.6$ & $1913.6 \pm 992.1$ & NS \\
\hline Peak E2 concentration (pg/mL) & $2794.8 \pm 1460.2$ & $2378.2 \pm 1662.5$ & $2854.1 \pm 1802.7$ & $2054.2 \pm 1145.4$ & 0.003 \\
\hline EL on hcg day (mm) & $9.86 \pm 1.81$ & $10.28 \pm 2.09$ & $9.57 \pm 1.74$ & $10.07 \pm 1.79$ & NS \\
\hline No of dominant follicle & $7.88 \pm 3.19$ & $7.84 \pm 3.26$ & $7.74 \pm 3.76$ & $6.85 \pm 2.97$ & NS \\
\hline No of COC oocytes & $12.37 \pm 4.66$ & $10.68 \pm 4.62$ & $11.41 \pm 5.69$ & $9.20 \pm 4.51$ & $<0.001$ \\
\hline MII oocytes ratio (\%) & 77.86 & 77.79 & 74.26 & 77.93 & NS \\
\hline No of PNII & $6.22 \pm 3.57$ & $5.86 \pm 3.85$ & $5.73 \pm 3.19$ & $5.57 \pm 3.45$ & NS \\
\hline Implantation rate (\%) & 35.52 & 32.89 & 32.08 & 19.92 & NS \\
\hline No of good quality embryo & $1.60 \pm 1.56$ & $3.76 \pm 2.71$ & $1.46 \pm 1.18$ & $3.01 \pm 2.02$ & $<0.001$ \\
\hline No of embryo transferred & $1.18 \pm 0.44$ & $1.21 \pm 0.41$ & $1.14 \pm 0.45$ & $1.24 \pm 0.48$ & NS \\
\hline
\end{tabular}


effect was not observed in patients with PCOS. According to their article, PCOS had a different response to stimulation in a wide range, and to the best of knowledge, different phenotypes were not assessed separately. The effect of basal testosterone levels in IVF cycles of patients without PCOS was evaluated in a study by Sun et al.(22) consistent with our results in PCOS patients, the authors concluded that although basal testosterone did not predict pregnancy outcomes, it was associated with the large follicles on human koryonik gonadotropin day, FSH dosage, and also that lower levels of basal testosterone might be related with poor ovarian response(22). Embryo cleavage kinetics were studied by Wissing et al.(23) with a small sample size. Contrary to our results, their study showed slower development to the 8-cell stage from fertilization in patients with hyperandrogenic PCOS(23). An article published in 2014 compared cumulative live birth rates among groups of patients with PCOS, isolated $\mathrm{PCO}$, and controls; their data revealed higher live birth rates in the group with isolated PCO compared with controls. This favorable outcome was not observed in the PCOS group and the authors claimed that this may be due to unfavorable embryo competence otherwise observed in PCOS(24). Again, in their study a general conclusion was drawn from a mixture of patients with different PCOS phenotypes.

The limitations of our study were its retrospective nature and relatively small sample size. The importance of the present study is in the evaluation of assisted reproductive technology (ART) outcomes of different phenotypes of PCOS because there is limited data in the literature that compares subtypes of PCOS in terms of characteristics and outcomes of ART.

\section{Conclusion}

To the best of our knowledge, this is a unique study assessing IVF outcomes in different PCOS phenotypes in an acceptable number of participants. PCO morphology provides easier stimulation; hyperandrogenemia provides better results in

Table 3. Comparison of outcomes of IVF cycles among all groups

$\begin{array}{llll}\text { Group } 1 & \text { Group } 2 & \text { Group } 3 & \text { Control p } \\ (\mathrm{n}=85) & (\mathrm{n}=38) & (\mathrm{n}=55) & (\mathrm{n}=84)\end{array}$

Biochemical pregnancy rate*

\begin{tabular}{lccccc}
$\%$ & 40.0 & 36.8 & 34.5 & 25.3 & 0.283 \\
$(\mathrm{n})$ & $(34)$ & $(14)$ & $(19)$ & $(21)$ & \\
\multicolumn{4}{l}{ Clinical pregnancy rate } \\
$\%$ & 30.1 & 36.8 & 30.9 & 22.9 & 0.425 \\
\hline (n) & $(25)$ & $(14)$ & $(17)$ & $(19)$ & \\
\hline
\end{tabular}

Ongoing pregnancy rate

$\begin{array}{llllll}\% & 24.1 & 25.0 & 23.6 & 20.5 & 0.930 \\ \text { (n) } & (20) & (9) & (13) & (17) & \end{array}$

The level of significance was accepted at $\mathrm{p}=0.05$ level, Chi square test was used, IVF: in vitro fertilization terms of good quality embryos. Multivariate regression analyses showed that easier stimulation is based on basal FSH level, group, and age. However, the end point was similar regarding biochemical, clinical, and ongoing pregnancy rates.

\section{Ethics}

Ethics Committee Approval: The study protocol was approved by the Local Ethics Committee of Zeynep Kamil Training and Research Hospital, Informed Consent: A consent form was completed by all participants.

Peer-review: External and Internal peer-reviewed.

\section{Authorship Contribtions}

Surgical and Medical Practices: Hüseyin Tayfun Kutlu, Belgin Devranoğlu, Concept: Selçuk Selçuk, Enis Özkaya, Design: Selçuk Selçuk, Enis Özkaya, Hüseyin Tayfun Kutlu, Data Collection or Processing: Ahmet Eser, Melda Kuyucu, Analysis or Interpretation: Enis Özkaya, Literature Search: Selçuk Selçuk, Belgin Devranoğlu, Kenan Sofuoğlu, Writing: Selçuk Selçuk, Enis Özkaya.

Conflict of Interest: No conflict of interest was declared by the authors. Financial Disclosure: The authors declared that this study has received no financial support.

\section{References}

1. Zawadzki JK, Dunaif A. Diagnostic criteria for polycystic ovary syndrome: towards a rationale approach. In: Dunaif A, Givens JR, Haseltine F, Merriam GR, editors. Polycystic ovary syndrome. Boston, Blackwell Scientific; 1992.p.377-84.

2. Dewailly D, Catteau-Jonard S, Reyss AC, Leroy M, Pigny P. Oligoanovulation with polycystic ovaries but not overt hyperandrogenism. J Clin Endocrinol Metab 2006;91:3922-7.

3. Azziz R, Carmina E, Dewailly D, DiamantiKandarakis E, EscobarMorreale HF, Futterweit W, et al. Position statement: criteria for defining polycystic ovary syndrome as a predominantly hyperandrogenic syndrome: An androgen excess society guideline. J Clin Endocrinol Metab 2006;91:4237-45.

4. Rotterdam ESHRE/ASRM Sponsored PCOS Consensus Workshop Group. Revised 2003 consensus on diagnostic criteria and long-term health risks related to polycystic ovary syndrome. Fertil Steril 2004;81:19-25.

5. Qiao J, Feng HL. Extra- and intra-ovarian factors in polycystic ovary syndrome: Impact on oocyte maturation and embryo developmental competence. Hum Reprod Update 2011;17:17-33.

6. Carmine E. Ovarian and adrenal hyperandrogenism. Ann NY Acad Sci 2006;1092:130-7.

7. Carmina E, Lobo RA. Prevalence and metabolic characteristics of adrenal androgen excess in hyperandrogenic women with different phenotypes. J Endocrinol Invest 2007;30:111-6.

8. Kumar A, Woods KS, Bartolucci AA, Azziz R. Prevalence of adrenal androgen excess in patients with the polycystic ovary syndrome (PCOS). Clin Endocrinol (Oxf) 2005;62:644-9.

9. Mamas L, Mamas E. Dehydroepiandrosterone supplementation in assisted reproduction: Rationale and results. Curr Opin Obstet Gynecol 2009;21:306-8.

10. Kim YJ, Ku SY, Jee BC, Suh CS, Kim SH, Choi YM, et al. A comparative study on the outcomes of in vitro fertilization between women with polycystic ovary syndrome and those with sonographic polycystic ovary-only in GnRH antagonist cycles. Arch Gynecol Obstet 2010;282:199-205. 
11. Balen AH, Laven JS, Tan SL, Dewailly D. Ultrasound assessment of the polycystic ovary: international consensus definitions. Hum Reprod Update 2003;9:505-14.

12. Hatch R, Rosenfield RL, Kim MH, Tredway D. Hirsutism: implications, etiology, and management. Am J Obstet Gynecol 1981;140:815-30.

13. Van Royen E, Mangelschots K, De Neubourg D, Valkenburg M, Van de Meerssche M, Ryckaert $G$, et al. Characterization of a top quality embryo, a step towards single-embryo transfer. Hum Reprod 1999;14:2345-9.

14. Alpha Scientists in Reproductive Medicine and ESHRE Special Interest Group of Embryology. The Istanbul consensus workshop on embryo assessment: Proceedings of an expert meeting. Hum Reprod 2011;26:1270-83

15. Gardner DK, Schoolcraft WB. In vitro culture of human blastocysts. In: Jansen R, Mortimer D editors. Toward Reproductive Certainty: Fertility and Genetics Beyond 1999. London, Parthenon Publishing; 1999.p.378-88.

16. Jamil AS, Alalaf SK, Al-Tawil NG, Al-Shawaf T. Comparison of clinical and hormonal characteristics among four phenotypes of polycystic ovary syndrome based on the Rotterdam criteria. Arch Gynecol Obstet 2016;293:447-56.

17. Gleicher N, Weghofer A, Barad DH. The role of androgens in follicle maturation and ovulation induction: friend or foe of infertility treatment? Reprod Biol Endocrinol 2011;9:116.

18. Qiao J, Feng HL. Extra- and intra-ovarian factors in polycystic ovary syndrome: Impact on oocyte maturation and embryo developmental competence. Hum Reprod Update 2011;17:17-33.
19. Sigala J, Sifer C, Dewailly D, Robin G, Bruyneel A, Ramdane N, et al. Is polycystic ovarian morphology related to a poor oocyte quality after controlled ovarian hyperstimulation for intracytoplasmic sperm injection? Results from a prospective, comparative study. Fertil Steril 2015;103:112-8

20. O'Neill KE, Senapati S, Dokras A. Use of gonadotropin-releasing hormone agonist trigger during in vitro fertilization is associated with similar endocrine profiles and oocyte measures in women with and without polycystic ovary syndrome. Fertil Steril 2015;103:264-9.

21. Ryan A, Wang S, Alvero R, Polotsky AJ. Prolonged gonadotropin stimulation for assisted reproductive technology cycles is associated with decreased pregnancy rates for all women except for women with polycystic ovary syndrome. J Assist Reprod Genet 2014;31:837-42.

22. Sun B, Wang F, Sun J, Yu W, Sun Y. Basal serum testosterone levels correlate with ovarian response but do not predict pregnancy outcome in non-PCOS women undergoing IVF. J Assist Reprod Genet 2014;31:829-35.

23. Wissing ML, Bjerge MR, Olesen AI, Hoest T, Mikkelsen AL. Impact of PCOS on early embryo cleavage kinetics. Reprod Biomed Online. 2014;28:508-14.

24. Li HW, Lee VC, Lau EY, Yeung WS, Ho PC, Ng EH. Cumulative live-birth rate in women with polycystic ovary syndrome or isolated polycystic ovaries undergoing in-vitro fertilisation treatment. J Assist Reprod Genet 2014;31:205-11. 